\title{
The Use of Proverbial Ideophones in Anaang, Southern Nigeria
}

\author{
Itoro Michael \\ Department of Linguistics and Nigerian Languages \\ University of Uyo, Uyo, Nigeria \\ E-mail: itoromich@yahoo.com
}

Received: 18-02-2014

Accepted: 02-05-2014

Published: 01-09-2014

doi:10.7575/aiac.ijalel.v.3n.5p.72

URL: http://dx.doi.org/10.7575/aiac.ijalel.v.3n.5p.72

\begin{abstract}
This research centres on Anaang ${ }^{1}$ proverbial ideophones and its relevance in communication in. Data for this work was gathered during several field trips undertaken to the four speech communities of Anaang to collect data on Anaang folklore, for the on-going research on the Lower Cross Languages Development Project (LCLDP) sponsored by the Linguistics Department of the University of Uyo, for the documentation and revitalization of the endangered languages in the Cross River Area. A vast number of data on proverbs were recorded during interview with the people on a folk session. From the recordings, data on proverbial ideophones were elicited and used for this work. This paper adopts the theoretical framework of Speech Acts theory for analysis. It has been observed that Anaang proverbial ideophones are rich in the use of style and language, as well as literal and contextual techniques. The contents as well as the contexts are carefully selected to reflect the socio-cultural background of the people. The application of proverbial ideophone is a special skill in speech, and requires a clear knowledge of the socio-cultural background of the people. This work is therefore, an invaluable foundation for cultural communication in Anaang, Southern Nigeria.
\end{abstract}

Keywords: proverb, ideophone, Anaang, language, communication, culture.

\section{Introduction}

Most African traditions still exist in oral form till today. Some of the genres of our oral traditions have gone into extinction, many more are highly endangered. In order to preserve the existing traditions, scholars have made tremendous attempts to document these oral traditions in either electronic or print format. Several studies have been carried out on diverse features and structures of ideophones in Nigerian as well as African languages. Considering the socio-cultural and linguistic relevance of ideophones in proverbial usage, it is therefore considered applauding to research on this important genre of Anaang verbal art. The focus of this work is on the actual description of the use of proverbial ideophones for communication in Anaang, using the theoretical framework of speech act theory proposed by Austin (1961) and developed by Searle (1969).

1.1 Importance of the problem

Proverbs and ideophones are aspects of African verbal art. Defining proverbs in terms of forms, Akporobaro and Emovon (1994), and Akporobaro (2004) refer to proverb as a graphic statement that expresses the reality of experience. Its beauty and sources of delight is that, what it says is readily perceived and accepted as truth. The origin of proverbs cannot be traced to any known author. For instance, proverbial usage in Anaang is always attributed to 'our forefathers' to show that it is ancient in origin with no known specific author. The fact that scholars have compiled and documented African proverbs/ideophones does not imply that these scholars are the originators or authors of these genres. Therefore, proverbs and ideophones are aspects of oral literature in African art.

Proverb is the exclusive genre of the adult male members of the Anaang traditional society (Michael, 2011, 2013). Those who are able to use proverbs effectively are known as 'born orators' (Messenger 1959). In the Anaang traditional setting, women and children were not expected to be heard in the public. A woman who expresses her view in the public was seen as a talkative rather than an orator. Orators reveal little reticence or difficulty about public expression ( Finnegen 2012). This is so significant in Anaang to the extent that; although a child is forbidden to use proverb, the adult will have to train him on proverbial usage, in a way that as soon as he grows into adulthood, he could be a good public orator. The proverb 'ayen akut ete idehe nsek' (someone who can say something about his father is not a child) is always used to confirm the fact the qualities of good parenting is often and more prominently seen in the behaviour of the child especially, as in his speech behaviour.

Proverbial usage features prominently in the Anaang traditional court setting. It is employed by the judge to exhibit a sign of wise and eloquent speech. It is used to shorten long speech as confirmed by the proverb 'iko keed akem anyie iwuo agwo' (a word is enough for the wise), 'etan eno nnjen unen; etan eno ndukpo, (caution to the two parties).

Proverbial usage has literary significance as a result of the connection of proverbs with other forms of oral literature like riddles, songs, orator, incantation, and stories (Harding 1994, Harding 2002 and Akporobaro 2006). For instance, in the pouring of libation among the neighbouring Efik people of Southern Nigeria, the following proverbs are used; 'Eteakpo etibe nnuk, eka akpo etibe; akukum-akukum emen esie ke usanya. (I am doing what my parents did) 'mma-mana ndikut inuho ebot', (my parents did it this way; it does not originate from me), 'atimme ama itotto abasi ituakka ison, 
(Anaang source) (I am paying homage to my superiors first before I take any action) These are proverbs used for incantations, libations or even stories to evoke authority from their ancestors. The Efik people communicate with their ancestors in proverbs to show that their gods are wise and that wise words should be used to address them.

The use of proverb is not restricted to incantations, libations, narratives, and songs but is also seen on judiciary and political occasions. In this context, proverb is used to make the speaker to speak with wit, humour and authority. Speakers apply this concept to attract the positive attention of the audience or listeners. These importance made Messenger (1995 p. 64) to conclude that in the Anaang settings, 'an orator should adorn his rhetoric with apt and appealing proverbs'.

Proverb is used to strengthen communal living in a traditional society. For instance, 'asawo adiaaha mkpo asin the idip ibom' has to do with 'two reptiles; different species of python, believed to be sharing one and the same stomach. This proverb communicates representational government or benefit. In this case, the success of a member of a community is automatically the success of all.

Proverbs are also used to instruct or advice. This is supported by the Anaang proverb 'ndinoono item afere afon nana edisinne ekpan' meaning (the best time for an advice or instruction to someone at the preparation stage). This is to say that 'to be forewarned is to be forearmed'. In other words, it is a good thing to offer an instruction as a guide to success, and not after failure. Proverbs could be cited in situations far from the original application. For instance; 'ibaaha ate aran aka abokko idai', (the sole purpose of the oil is for consumption even if it is exported to other places). The implication of this proverb is that 'man is naturally born to suffer'. The truth is that every human being is unique and has a unique responsibility to play in life just as oil is meant for consumption. The proverb in this sense is applied as a warming against irresponsibility and excuses. In order to intensify the warnings or instructions, ideophone comes into play. In this study, ideophone is represented as mimic noun, intensive noun, and descriptive element in proverbs. It is defined as a special concept, which conveys a kind of idea-in-sound and is commonly used to add vividness to a description. It is used with considerable rhetorical effects to express emotion. Ideophones are somehow onomatopoeic, but the acoustic impression conveys aspects such as action, manner, condition or intensity (Finnegan 2012). They are often used to add vividness and emphasis to a narration or speech. Therefore, ideophonic expression in proverbs is applied to intensify instructions, warnings, advice, ideas, meanings and actions.

Proverbs are often presented in poetic forms, which make them stand out from ordinary sentences. The composition of some proverbs are made up of sound symbolic speech form such as ideophone. For instance in the Anaang proverb 'ama-akop tap ada-nuho' (you will surely surrender by force), the proverb is used to sound as a warning to a stubborn person; that stiff-necked people surrender only at critical dangerous points. The ideophone here is 'tap' meaning 'unexpected deep and humiliating pains'. The usage is quite symbolic and communicates the intensity of the effects of stubbornness

Consider the proverb; 'nana ayen ikpon akummo ikan ke idim, idun edop miak; ilim adiiben ikpon, ilun efut nwook nwook', (When an only child set fire inside the stream, the village kept mute 'mak'; when the stream drowned the only child, the village shouted furiously 'nwook nwook'). The proverb is used in the context of equal right and justice irrespective of status, age and other conditions. The ideophones here occur in opposition; 'miak' depicts complete silence, while 'gwook' shows furious noises. The opposition of complete silence is used to intensify complete neglect of the first action while the furious noise depicts the intensity of the furiousness on the second action.

\section{Proverbial Ideophones}

The term proverbial ideophone is coined from two words: Proverb and ideophone. As mentioned earlier, proverbs and ideophones are two existing aspects of African verbal art used in cultural communication. Ideophone is found in the network of ideas and sounds from which the artiste draws; the meaning is in the aesthetic tradition and its interpretation before the audience. It is in the social and cultural setting that makes the past and present world of the people; the meaning is in the vital and dynamic nature of the words (Noss 2001:269).

Many scholars have worked on ideophones in African languages from diverse approaches. For instance, Ameka (2001), viewed ideophones from a phonosemantic class in Ewe, while Kabuta (1998) focused on the grammatical features of ideophones in Ciluda (a Bantu language). On the other hand, Kunene (1978), described ideophone as a linguistic rebel using Sotho language. Various other scholars have related the aspects of ideophones to diverse phenomena in various ways. An extensive literature on ideophones in Nigerian languages span over its meanings, phonological, syntactic and morphological structures. Udoh (2009) for instance looked at the structural pattern of ideophones in Leggbo as having a reduplication feature. The essence of the reduplication is to intensify an action. In line with this view, Egbokhare (1990), however added that although the use of ideophone in a language like Emai intensifies an action, ideophone should be viewed as sound-symbolism with natural and predictable meanings. This same idea was echoed in Childs (1994). Ekere $(1988,1996)$ whose focus was on Ibibio, perceived ideophones from emotional point of view, which are normally made to obey harmony between sound and sense. Dingemanse, defined ideohpones as 'marked words that vividly evoke sensory events' The general notion of ideophones is centred on an onomatopoeic concept which describes or qualifies manner, colour, sound, smells, actions state or intensity (Doke 1935 p.118). Noss $(1975,1985)$ and Blench (2009) however differed slightly. Noss examined the use of ideophones folktales, narratives and poetry to explore the creative aspect of these phenomena in Gbaya. Blench (2009) have collected data on ideophones for some twenty languages in Nigeria and Cameroun, and run workshops in Cameroun for several languages and asserted with the speakers that 'ideophones were a relatively fixed pool and that the correct ideophone would be known to competent speaker'.

Proverb on the other hand is seen as a piece of folk wisdom and a product of intelligent reflection expressed with terseness and charms following Finnegan (1970), Maduka (1988) and Okpewho (1992). It is classified as folk wisdom 
because proverb contains a truth about life, accepted by the people and appeals to their imagination by the neatness and beauty in which it has been framed. For instance, Yankah (2012), using Akan as the basis, viewed proverbs in the context of rhetoric. Brandbury (2002) viewed proverbial usage as a concept which adds new meaning to the content of communication. In the Nigerian settings, the use of proverb cuts across all linguistics communities; few of such include; Hausa (Salamone 1976), Yoruba (Arewa and Dundes 1964), Niger Delta (Oduran \& Oduran 2006), Efik, Ibibio and Anaang (Simons 1955, Messenger 1962, 1959a, 1959b, Mensah 2010) among others.

In this work we look at proverbs as metaphorical statements which depict general truth while the contextual meaning is culture specific. As argued by Finnegan $(1970,2010,2012)$, proverbs reinforce or foreground an argument. Ideophonic expression is therefore one of the poetic devices incorporated into proverbial usage to foreground an argument or to intensity the truth. Formulation of proverbial ideophone is shaped by actual historical events, coupled with observations of the universe including creatures, vegetations as well as the general behaviour of humans, animals, within a specific environment. The communication aspect of proverbial ideophone usage is highly appealing and adds spices to eloquent speech.

\section{Theoretical approach}

This work adopts the theoretical framework of Speech Acts theory proposed by Austin (1961) and developed by Searle (1969). Speech Acts is considered as the basis or minimal units of linguistic communication. Speech Acts theory states that all linguistic units involve linguistic acts. The production of a sentence token under certain conditions is an aspect of Speech Acts. For instance, if someone considers a noise or a mark on a piece of paper as meaningful, the assumption is that it was produced by human being with certain kinds of intentions and that the intentions are of a very kind peculiar to speech acts. In this sense, a theory of language is a theory of action since speaking is rule-governed form of behaviour with formal features ( Schriffin 1994).

According to Stross (1974 and Sherzer (1992), meaning and speech acts are closely related since every meaningful utterance can be used to perform particular speech and every possible speech act in principle can be given an exact formulation in sentence. Therefore communication following Lyons (1977), Makaryk (2000), Austin (1961), and Searle (1979), is based on one who concentrates on the uses of expression in speech situations and on one which centres on the meaning of an utterance.

Dixon (1991) classifies speech acts on the basis of manner of speaking, speaker/hearer evaluation of the contents, and the effects of the speech on the hearer. It is also classified on the basis of how information flows from the speaker to the hearer, types of speech, source of the information and the length of the speech. Other forms of speech acts as presented by philosophers (Searle 1979), are said to have illocutionary forces (acts performed in saying something), perlocutionary forces (like persuading and dissuading) and locutionary forces (the spoken act, which involves talking and speaking).

Speech acts enhance effective communication. People's reaction in speeches varies according to what kind of speech act they have applied. Speech is controlled by rules that are learnt as a part of the culture of the people. Speech is skilled in the sense that it requires the background knowledge of the people. The rules and the skills are acquired and vary from society to society. Language functions as a link in concerted human activity. It is a mode of action, where speech acts control the people's activities. It is also used to reinforce social relation (Hymes 1972, 1974). Speech acts theory is used for this research to show how information flows, and to describe the manner of speech in terms of acting, miming, agreeing, reporting, announcing, persuading and ordering. It is also applied to describe the effects of speech including the mode of proverbial ideophones in Anaang as used for socio-cultural communication.

\section{Method}

Proverbial ideophones for this paper were selected from a range of data on Anaang folklore collected during series of field trips to the four speech communities of Anaang. The data was collected for the on-going research on the Lower Cross Languages Development Project (LCLDP) sponsored by the Linguistics Department of the University of Uyo, for the documentation and revitalization of the endangered languages in the Cross River area. A vast number of data on proverbs were collected from 80 native speakers, purposefully selected. Focused group interview and participant observation methods were employed for the data collection procedure. The data was recorded with a tape. From the recordings, data on proverbial ideophones were elicited and used for this work. The recorded data was transcribed and classified based on usage. The analysis was centred on the pragmatic and stylistic implications of the selected proverbial ideophones.

\section{The Data on Anaang Proverbial Ideophones.}

In this section, data on Anaang proverbial ideophones are presented as communicative precision tools. The presentation and analysis of the data ${ }^{3}$ in this section is classified according to their functions as follows:

I. Humility

1. Àsañá úsúk-úsúk ínàaghà ùsùñ ùdua ínyammá íkpóñ ágwó.

\section{Walking slow-slow sleep-not road; market sell-not leave person.}

Slow but step-by-step movement is not a symbol of stagnation.

The ideophone in this proverb is úsúk-úsúk. The focus of this proverb is on the success of someone who starts struggling late in life. He can never stop half-way 'sleep on the road' and cannot be despised in the public for his lateness 'market considers no one as being late'. The ideophone úsúk-úsúk is applied to show that it's never too late to take an initiative. It is a declarative statement that is used to strengthen and encourage the weak ones to try and take a step. 
2. Tèp tèp áyóhó ábán

Drop drop fill pot

Little drops filled the pot.

The ideophone in this proverb is 'tèp tèp; a slow but steady and continuous sounding drops. The ideophone 'tèp tèp' stands for a humble beginning. The proverb employs this ideophone for a vivid description of the drops which depicts a slow pace or a humble beginning. The ideophone occurs purposefully at the beginning of the proverb to place emphasis on a humble beginning or a start which may not be as clear-cut and fast as expected. The proverb ends with a triumphant result which is the expectation of any investment or mission- 'abundance, completion and satisfaction'.

II. Cheating

3 Éwót ámá-á ányíe,áwàaná mímè únèn; únèn ámá-á ányíe, ànyé fùrùuuk àkòm.

Goat when has shares with fowl; fowl when has fly roof.

The goat shares what it has with the fowl, but the fowl is cheating the goat.

The ideophone here is 'fùrùuuk', a sound of flying. Up till today, the goat is used to describe a foolish, innocent and an inexperienced person. This class of person is always cheated by the other partner as depicted by the ideophone 'fùrùuuk'. The Anaang society frowns at this and uses the ideophone 'fùrùuuk' to express the gravity of the cheating on an innocent love and caring partner. The proverb starts with communal life and ends with selfish and falsehood cheating. The theme of this proverb is on communal living. The mood is declarative reporting a case of cheating discourse which is a representation of the spoken act.

4. À-súk adia nnè ébót, a-súk anwòn nnè ébót, ama-a kòp mmaak- úyò ébòt afò údiònoké You eat with goat, you-continue drink with goat; when-you hear voice goat, you know not. You dine regularly with the goat; when the goat bleats you pretend not to recognize the voice.

The aspect of the bleating of a goat is the ideophone in this proverb. The goat is the target here, which depicts a helper or a closer person. The ideophone 'bleating' depicts helplessness. How can you move, sit, eat, drink and interact closely with somebody only to abandon that same person when he is in need, with all forms of irrelevant excuses; and with the pretext of not knowing or remembering that person? The society frowns at this, using this proverb to express the intensity of their bitterness. This proverb is therefore used to correct the act of neglect, selfishness, uncharitable, short-sighted behaviour and the habit of non-reciprocation. The premise is that humans should learn to render a helping hand to a known person when he is in crises or need; be it material, moral, financial or otherwise. The mood of the proverb is pseudo-imperative with emotional feelings of disappointment.

III. Hard work/skillfulness

\section{5. .kútip mmá mmá-a! atì ìyà.}

\section{Do not miss mmá mmá miss iya}

Do not miss both the salutation and its response.

Literally the proverb focuses on naturally occurring, formal talk-in-interaction (phatic communion), because this is the basic stream of verbal behaviour that underlies all other patterns of interaction. The proverb is meant to act as a piece of advice that if one fails in leadership role, one should not be a passive servant/follower.

Contextually, the proverb is applied to encourage someone to quickly grasps the next available opportunity if the first one had slipped off or escaped. It is an imperative statement that is used to encourage a second trial and to warn someone to always be on the alert to prevent missing out at both ends.

6. Àsásá átè 'ànwáná ányié ànwáná ányié!'; èbòm ésit ìkòt áte 'ànyiè iki-tié tiè ifòró!'

Àsásá says 'struggle get struggle get!; èbòm inside bush says 'who sit sit prosper!.

The asásá bird says 'struggle and be rich, struggle and be rich'; the bird inside the bush says 'can a lazy person ever prosper!' (There is dignity in labour).

'Anwáná ányié ànwáná ányié!'; and 'ànyiè iki-tié tiè ifòró!' are the diverse interpretations given to the songs of the birds 'asásá and èbòm' respectively to liken prosperity to hard work and poverty to laziness. Traditionally, prosperity is a manifestation of hard work, while laziness breeds poverty as declared by the sounds of the two birds. The ideophonic expressions in this saying are used to encourage hard work and discourage laziness.

7. Aásásá ámá-bó sá mmá-kap mbòijó nwèt itien!; ebòm èist ikòt abòòró, ákpèkap ádiònó A B C Di-i! ákpèkap ádiònó A B C Di-i!

Asásá when said since I have then pass book five!; ebòm inside bush answered, does not know A B C Di-i! does not know A B C Di-i!

When ásásá brags 'I have completed my primary education; the unlearned ebòm replied 'you cannot even be expressive. (Empty vessels make the loudness noise).

The quotations from the two birds are interpretations given by the Anaang people to the echoes of the sounds emitted by these birds especially in the morning and evening hours. When ásásá echoes, tia-tia-tia -tia-tia-tia-at!, ebòm echoes 
ku-ku-ku-ku-ku-u!. The content of this quotation is adopted into proverb formation to give information that; obtaining a certificate is one thing and being literate is another thing. This is equivalent to the English proverb which says that 'an empty vessel makes the loudness noise'.

Actually, birds do not go to school but humans do. The ideophones are used metaphorically to communicate man's unserious behaviour in the present society. The proverb is therefore emphasizing on the need for skillful specialization, pragmatic and real practical approach in the exhibition of one's profession. The contrastive ideophones are applied to heighten the effects of pride and ignorance. The mode of this proverb is declarative, condemning 'inefficiency'.

IV. Curruption/suppression.

8. Àdón-dón-dón ímàaghà íkò; àbùrù -bùrù -nwàk ásé ákpeké ésòp.

Eloquent smooth finish not talk; mix-confuse usually cut court.

Eloquent speech does not settle cases; bribery shortens court cases.

In the ancient traditional judiciary system, a good judge was applauded for fair hearing and for his choice of eloquent and smooth words 'don-don-don' in settling cases. This is not the case in the present day Anaang. Taking of gift 'àbùrù -bùrù -nwàk' shortens all cases without fair hearing. These two ideophones are used sarcastically to ridicule corrupt judges who are blinded by bribery. The extent of corruption is expressed in the proverb in (example 9).

9. Usen iko ayen ugweene, elim alep nyiik nyiik; usen anyiewo, elim alep saha saha.

Day case person poor, rain rain very heavy; day rich person, rain fall lightly.

The offence of a poor person attracts heavy penalty, while that of a rich person attracts light penalty.

The ideophone 'nyiik-nyiik' depicts heavy weight or the intensity of the suppression of the poor/indigent. While 'saha saha depicts a lighter action taken when a case involves a wealthy person.

Contextually the proverb implies that wisdom cannot prosper in a corrupt environment. It is a declarative sarcastic statement which ridicules corrupt wise men who suppress the poor but favour the rich in the society.

$\mathrm{V}$. Vengeance

10. Ágwó ǹkárá ǹkárá, Àbàsì ǹkárá ǹkárá; Ágwó súurúk ufò̀k Àbàsì tèm àkò̀m

Man crafty crafty. God crafty crafty; man enter house, god hits roof.

God punishment changes intensively in line with man's crafty behaviour

(You surely reap what you sow).

The ideophones used in this context are: súruúk and tèm. Two images are presented here; man and God. God changes in line with man's crafty behaviour.

This proverb means that you cannot cheat someone who takes care of you because you will not be able to escape from his wrath. At the same time, it is used satirically to ridicule a crafty man when he is duped by a stronger crafty person. This proverb is used as a warning against dubious behaviour because the end is always disastrous. This behaviour is echoed in the following proverb.

11.Inó átó ìnó ìtà-toop, Awasi atie ke anyong adueet imam.

\section{Thief hit thief blow God sits in heaven laughs}

When thieves battle each other, there is no victor.

Two thieves are involved in this proverb. The ideophone is 'átó ità-toop' and dueet. The proverb is applied to show that two strong people cannot give up in any case. They are always struggling, arguing, disagreeing strongly and fighting for one thing or the other without an end because neither of the parties will be willing to surrender. At the same time criminals, represented by the word 'ìnó', can only be handled by people who are as strong 'átó ità' as the criminals. The proverb also means that a criminal is always fast at accusing another criminal. The theme of the proverb is on the law of vengeance on the act of violence or any other criminal act. The tone of the proverb is satirical challenging, with a pseudo-imperative mood. The context depicts a lawless society which is directly implied to that of a thief.

\section{A-tún, n-tún; a-dèèp n-dèèp, aféré akwèèné.}

You-dig, i-dig; you-dip, i-dip, soup finish.

If you waste, I will do likewise, you preserve I do likewise and nothing will remain.

'Tún' is an aspect of digging deep; 'dèèp' involves dipping something or hand/finger inside a liquid substance or soup. The proverb is a direct expression of bitterness towards cheating, unfaithfulness and extravagant spending. There is no need to continue tolerating someone with any of these characters. The only way out is to join him so that he too will become stranded, starved, and empty like the partner whom he intended to cheat since the two of them have exhausted their resources. The proverb shows that there is need for one to adhere to instructions because the effects of irresponsibility can boomerang immediately. The mood of the proverb is pseudo-imperative, and satirical; challenging the act of wastefulness. 
13. Atùn-tùn áták-ták áse-e ásùùnò ke ekpà ndidùòk.

Roam-roam grasshopper always rest in gizzard bird.

A restless grasshopper usually ends in the gizzard of a bird.

The focus here is on restlessness 'atùn-tùn'. The ideophone 'atu-tun' intensifies the weight of stubbornness, restlessness and stiff-neckedness. The proverb does not have a direct meaning. So long as someone decides to be stubborn, not heeding to advise, the end of such a person is always disastrous. It has a declarative mood with strong warning against stubbornness 'atùn - tùn áták-ták. The speaker declares that the end of such a person is always disastrous and deathly because the person will surely fall a prey to devourers.

14. Ewá ámá ákpoì ànsí-nyíé ádóm ásén.

Dog when bark owner, bites visitor.

If a dog barks at its owner, it can bite a stranger.

Dogs are expected to be highly friendly with the owner. But in a situation where the dog barks at the owner, it means the dog has been provoked to anger, and can bite a stranger at that point. The proverb implies that if a child insults his parents/guardians; such a child can fight with any other person. The ideophone barks 'ákpoì' and bites 'ádóm' depicts bewilderment, wrath and brutality. The dog is symbolic of a brutal person who has no respect for people within and without irrespective of what he benefits from these people.

\section{Akán-kán ibònnó ke àkòm úfòk àgwò nkáná.}

\section{Metal gong shout-not on roof house person nothing.}

A metal gong cannot be heard in someone's compound without reasons.

A metal gong is used for proclamations in traditional Anaang. The ideophone 'akán-kán bòn' stands for the sound of a wooden gong. The proverb implies that there is always a root cause to every problem or success.

VI. Impatience

16. Umé - ùkàk ánám àkpàkpà ákprààk ké íkán.

Endure-tired makes corn burst for fire.

Overbearing makes the corn to pop on fire.

In our day to day engagement, it is believed that we are bound to react in proportion to pressure. This proverb can be used to justify the extent or the effects of the pressure. The proverb is used to justify the act of protest, rebellion, deviant behaviour, non-conformity, separation, dismissal, withdrawal among other negative sanctions after several warnings or exhausted patience/overbearing. The action cannot be reversed because all possible peaceful avenues had been exhausted umé - ùkàk 'prolonged patience'. This therefore gives room to 'protest' which is the ideophone 'kprààk'. The ideophone here depicts public demonstration. It is used to intensify the force with which the affected persons reacted: noisy, bustling, popping like the roasted corn. The corn here is a symbol of a man who is faced with series of problems. The communicative strategy is direct. The mood of the proverb is declarative, with authority and strong support of the action. The beginning of the proverb justifies strongly the cause of the action taken. The content has nothing to do with the corn, it is merely depictive.

17. Sé ébót akút ádòp úyo ákpón ákàn sé únèn ákut ádúáijá.

What goat see keep quiet big pass what fowl see shout.

What the goat sees and endures is bigger than what the fowl sees and raises an alarm.

The goat is seen as a patient and quiet creature. It can endure hardship. Whereas the fowl is seen as being very lousy, impatience and fearful. It cannot endure even the least problem. Naturally, the fowl can raise alarm over nothing compared to what the goat can endure. Comparatively, the goat cannot be easily frightened by a mere sight.

This proverb is used in two contexts. When somebody is tired of a situation and decides to take certain actions without necessarily sharing his encounter with others. When persuaded by friends to either have a second thought or reverse his decision, the fellow can back up his decision with this proverb to show that he had encountered much problems but cannot narrate any.

Secondly, it is used to describe the comparative nature of different individuals. Those who are cowardice, and impatience are subject to unnecessary complaints over trivial matters. Whereas patience and brave persons can quietly pass through tribulations without complaining. This proverb is therefore applied as a warning against nagging, impatience and unnecessary complaints. The ideophone in this context ádúáijá depicts quick and uncalculated complaints associated with alarm. This ideophone emerges as a vivid and versatile communicative device well repaying analytic attention. 


\section{Akíkò ibà íkpòòkkó àkòm kèèt. Cock two crow-not roof one. \\ Two cock cannot crow on the same roof.}

The 'cock' signifies kings or leaders, 'to crow' signifies leadership voice/role, 'one roof' stands for the same domain. Ideally, two cocks cannot crow on the same roof. Only one has the inherent right to crow no matter the numbers of cock on that particular roof. Traditionally, storey building was not common in the Anaang nation, people lived in thatched buildings; which, of course was not too high. The roof of these thatched buildings therefore provided a serene for the cock to relax. The authority for only one cock to crow on one roof is the work of nature, which cannot be modified even by civilization.

This proverb is used in the context of leadership/kingship. Two or more kings cannot rule or govern the people at the same time. One community cannot have more than one head at the same time, as this will lead to a state of anarchy. The Anaang people are of the view that if the animal kingdom can have orderliness in leadership by allowing only one cock to crow at a time (on one and the same roof), then humans should be as orderly as the fowl kingdom and respect the leadership roles of the nation. This proverb therefore applies to settle leadership/kingship disputes in the family, and the community at large.

This proverb goes beyond kingship to the context of specialization. In any given unit, there is always an outstanding leader, others are expected to be the followers no matter how competent they are.

\section{Irresponsibility/waste}

19. Kú-dé nkániká úfòk Abàsì, amia kan-kan-kan, ádòn ágwo ke úfòk,atimme ádá ké ésién.

\section{Don't-be bell house God,ring put people for house wait for outside.}

Do not behave like the church bell, which directs people inside but waits outside.

The proverb makes use of a sounding-bell 'kan-kan-kan' as the ideophone to intensify the continuous efforts that the announcer 'bell' has made to direct, encourage and motivate others while he remains stagnated. The bell here is allegorical of a motivator who refuses to grow, an instructor who cannot participate or play any role; a detector, who enforces discipline when he himself is a tyrant, a talkative who kept reminding people of what others did but conceals his own activities. This proverb frowns at such characteristics.

\section{Mián-mián kpùd kpùd átèm été ádè ékpó.}

\section{Eat-eat, swallow-swallow keep man that masquerade.}

Gluttony renders someone wretchedly poor.

Mián-mián kpùd kpùd are sounds produced when somebody is eating; masquerade symbolises extreme poverty. A glutton man does not think of preservation. He is always out to consume all that he has without reservation 'Miánmián kpùd kpùd'. This of course renders him poor. The proverb is a warning on extravagant spending. The meaning is directly implied to 'serving for a rainy day' in other not be rendered wretchedly poor. The proverb opens with the ideophones 'mián-mián kpùd kpùd' to show that wasteful youth is the root cause of adjunct poverty.

\section{Mmédèp mmà, ndí-toì àtèp!}

\section{I-rain finish, I- now drop slow!}

I have been exhausted and worn out of strength.

The ideophone 'toì àtèp' is metaphorical, depicting weakness. The proverb starts with the past, 'mmédèp mmà which is reminiscence of wasteful strength, wealth, affluence, and good health and ends with the presence, ndí-toì àtèp! which depicts helplessness, handicapped, poverty, weakness, depression, ill health, and stress among others. The speaker uses the icon of rain drops to depict his present situation as 'helpless'. He cannot give any support to anybody; be it financial or material because the strength has gone out of him. He at this point is relying on charity for survival. Sometimes this proverb is used sarcastically as a cover up by those who are self centred when somebody requests a helping hand from them. The tone of the proverb is pathetic, declaring that somebody's present helpless situation is as a result of his wasteful past. The ideophone 'toì àtèp, intensifies the helpless/wretched end of wasteful past.

\section{Awo-nwààn ádiòk áfèrè ibòk ámen ùsùn íkán íkán.}

\section{Woman bad soup cook swallow foofo fire fire.}

A bad cook eats hastily.

This proverb has a literal meaning on a bad (female) cook. Since her soup is not palatable, she will have to eats hastily so that someone else will not meet her while eating and probably mock at her. 'ikán íkán' is the ideophone signifying speedy, hasty and intensive aspect of negative reaction. The proverb centres on a high level of irresponsibility. Contextually, an offender always acts hastily to clean up his mess to avoid being suspected or exposed. The semantic implication is on concealing ones guilt in a smart, hasty, harsh, and arrogant way, rather than remorse.

IX. Socials 


\section{Ikpòòn ínnékké èwuí.}

\section{A lonely dance not group steps.}

A solitary person cannot dance a group dance.

It is true that a solitary person cannot be selected to join a group dance. He is always abandoned and despised. 'Ewuí' here is the uniform steps and foot stamping by the dancers. Contextually, an indigent cannot be recommended or included in any public or group outings because of his poor situation. The proverb is pseudo-imperative, with sad mood and pity on the way the less privileged are being neglected and abandoned by the society. It is true that a solitary person cannot join social functions. The ideophone 'ewui' depicts the rhythm of a uniform group dance, which signifies 'strength', which cannot exist in the life of a solitary person (literal meaning).

\section{Discussion}

The proverbial ideophones selected for this work are based on various environmental and cultural behaviour of the Anaang society. There is a warning against stubbornness (example 12), lawlessness (10, 13,\& 14), irresponsibility, greed, waste (20-22). The tradition is against bribery and cheating, corruption and suppression (3, 4, 8 \& 9) for, there is vengeance for every evil action $(10 \& 11)$. The tradition encourages a humble beginning/investment $(1 \& 2)$, skillfulness ( $6 \& 7)$, and reminds the people to always be at alert (5) in order to succeed. These characters cut across a wide range of a true oral African society (Harding 1994, Finnegan 2012).

The significant of proverbial ideophone is determined by the situation or context of usage. The characteristics of the selected data is outlined as follows;

i. Contrastive oppositions: the selected data make use of contrastive oppositions. The sense of opposition is as used in this context depicts differences in attitude, picture or sense. The contrast lies on the ideas not the words itself. Contrastive subjects are governed by complex sentence presentation, thereby presenting two opposed ideas in contrastive clauses as seen in the following examples. Stealthy escape vs noisy landing (9), hard work and laziness (6) slow beginning vs successful completion (1), communal life vs selfish, egoistic, withdrawn behaviour $(3,4)$, leadership vs followership (5), riches vs poverty ( $20 \& 21)$, specialization and vain ignorance $(6,7)$, waste vs preservation (10), criminality vs honesty $(8)$, patience vs impatience $(15 \& 16)$, extravagant spending vs poverty $(11,10)$, overbearing vs explosion (15), weakness vs strength (23). The opposition is done in a systematic way, so that, verb contrasts with verb $(10,11,16,17)$, adverb with adverb (9), and noun with noun $(5,7,8)$, verb phrase (6), and noun phrase (7) in that sequence.

ii. Metaphorical/symbolic expressions and allegory: Proverbial ideophones make use of metaphorical and symbolic expressions to intensify contents and meaning. The ideophones of 'rain drops (1) symbolises a humble beginning, the restless grasshopper, barking dog (13) signify stubbornness. The goat in $(3,4, \& 16)$ is allegory of 'love'. Corn, hen $(16,17)$ represent impatience. The meaning is contextual based. For instance, what has the sound of a bird in (7) got to do with literacy? Birds do not go to school. The images are completely allegorical using existing icons to represent ideas, actions and events.

iii. Repetitions: Repetition of sounds or words for instance dominates the scene in most of the utterances. This can be seen in (examples 1, 2, 4-6,8 -13, 19, 20,22). Repetition communicates the intensity of the meaning attached to the action. For instance, 'ǹkárá ǹkárá', 'usuk-usuk' in $(9 \& 1)$ communicate the intensity of sense and action in this speech respectively.

iv. Miming/depiction: The image of birds, animals, rain, corn, woman are used to set up a depictive interpretive frame, evoking participation effects into the listeners. Depiction here makes proverbial ideohpones to be represented in a performance and dramatic scene in communication. The communication cuts across non-speech sounds like the miming of the sounds of the bird (6,7), water/rain drops $(2,9,21)$, swallowing (20) and bustling of the corn (6) which depict actions.

Anaang proverbial ideophone communicates cultural identity. Its contents clearly demonstrate culture specific truth( Etim and Michael 2012). For instance the truth in the data in (3) is a culture specific truth. The fowl might be viewed differently by different other cultures. While Anaang views it as a symbol of unfaithfulness in this context.

Anaang proverbial ideophones like the Ibibio and the Efik proverbs (Ukut 2010, Mensah 2010), have inherent peculiar characteristics different from ordinary constructions. The meaning is culture bound, relative, contextual, and sometimes literal. This genre makes use of impolite, gnomic but terse sentences for vividness, and emphasis. The use of metaphor, symbolism, allegory, imagery and repetition, clearly portray the choice of language in speech/ usage to depict a true sense of events, ideas, icons, actions, among others (Branbury 2002, Okpewho 1992)

The proverbial ideophones as presented in this work are completely symbolical, metaphorical allusive and allegorical. The activities, fate and destiny of man are shaped by his environment just like other creatures. It application shows a clear pictorial and sensory expression. Figurative expressions are used to convey abstract ideas in an imaginative way. For instance, the idea of bribery in (example 8) is conveyed by the ideophone 'buruburu nwak'

\section{Conclusion}

The research focused on naturally occurring everyday interaction as the basis of verbal interaction in socio-cultural communication. Proverbial ideophones are derived from the experience on everyday interaction and observation. The emphasis is in the depictive, performative and dramatic images in verbal utterance. Speech acts can be a representation of verbal utterance. The presentation is data driven, taking into consideration, the pragmatic and literary implications of proverbial ideophone in socio-cultural interaction. Proverbial ideophone is used as an instrument of inclusion or exclusion in communication. Therefore, the cultural background of the speakers is highly significance in its application and the understanding of its usage. 
Like any other proverb, proverbial ideophone is highly restricted in usage in the Anaang traditional setting. The young ones including messengers are prohibited from using proverbs in Anaang as well as the Ibibio and the Efik communities of Southern Nigeria. They can only learn them. The essence of this restriction is to avoid the creation of communication gap since proverbs do not relate meaning to content but to the context. Proverbs are words of wisdom and wisdom is attributed to age. Therefore, a young man, in Southern Nigeria, by virtue of his age is not vast enough with wisdom. He cannot be wiser than the elders, and as such is prohibited from addressing the elders with proverbial words. The paradox is, despite this restriction in usage, the young ones still learn this genre with eagerness and preserve them for future use.

The use of proverbial ideophone in speech poses some form of socio-cultural constraints to language communication. In this case, the listener will have to learn the socio-cultural constraints and also understand the cultural background of the people in order to understand the concepts and ideas in the speech since proverbial ideophones have more of contextual than literal interpretation. The meaning of proverbial ideophone is highly contextual relative to the cultural environment, when translated into English, the contextual implication is lost because Anaang and English do not share the same cultural background. For instance, mma-mma in (3) is a special manner of greeting peculiar to only the Anaang people and has no English equivalent if it is translated.

In conclusion therefore, one would say that proverbial ideophones are the model for socio-cultural communication, daily interactions and experience defined by the choice of words in speech. To capture and appreciate the use of proverbial ideophones, one must be highly familiar with the levels of social interaction at which individuals and group identities are being constructed. In Anaang, as well as other parts of Southern Nigeria, proverb is said to be of greatest significant at levels of communication; both formal and informal including legal cases, political transactions, petitions, stories, abuses, religious practices, songs or the art of rhetorical conversion. With the use of ideophonic expression in proverbs, speakers of Anaang have rhetorical and emphatic tools for effectiveness in communication. This work is an invaluable foundation for effective communication. The use of proverb as a tool for cultural communication and transmission of the people's culture therefore cannot be over emphasized.

\section{References}

Amaka, F. K. (2001). Ideophones and the nature of the adjective word class in Ewe. In, F. K. Erhard Voeltz and Christa Kilian-Hatz (Eds.) Ideohpones, (pp25-48). Amsterdam: John Benjamins,

Arewa, Ojo, and Alan Dundes. (1964). Proverbs and the ethnography of speaking folklore.

American Anthropologist 66:70-85.

Akporobaro F.B.O. and Emovon J. A. (1994). Nigerian Proverbs: Meanings and Relevance Today. Lagos: Department of Culture, Federal Ministry of Information and Culture.

Akporobaro, F. B. O. (2004). African Oral Literature, (2 $2^{\text {nd }}$ ed). Lagos : Princeton Publishing Company.

Akporobaro, F.B.O. (2006). African Oral literature. A Literary -Descriptive Approach. Ikeja-Lagos; Princeton

publishing Company.

Austin,J. R. (1961). How to do things with words. Harvard: CUP, Mass.

Barber, K. (1995). African-language literatures and postcolonial criticism', Research in African Literatures 26, 4: 3-30.

Blench, R. (2009). The sensory world; ideophones in Africa and elsewhere.Http://www.rogerblench.info/RBOP.htm

Bradbury, N. (2000). Transforming experience to tradition: Two theories of proverbs use and Chaucer's practice. Oral

Tradition 17:261-89.

Childs, G.T. (1994). African ideophones. In Hinton Leanne, Johanna Nichols, and John J. Ohala (Eds.). Sound

symbolism, (pp 178-204). Cambridge: CUP.

Dingemanse, M. 2011. The Meaning and Use of Ideophones in Siwu. Ph.D. dissertation. Nijmegen: Max Planck

Institute for Psycholinguistics/Radboud University.

Dixon, R. (1991). A new approach to English grammar on semantic principles. Oxford: OUP.

Egbokhare, F. O. (1990). A phonology of Emai. An unpublished Ph.D. Dissertation, University of Ibadan, Ibadan, Nigeria.

Ekere, Michael. E. (1988). Ideophonic expression in Ibibio. An unpublished PhD Dissertation, University of Calabar, Nigeria.

Ekere, M. E. (1998). Nominal ideophones in Ibibio. Journal of humanities Vol.5, 25-35.

Etim, E.P. and Michael, I. (2012). A pragmatic analysis of Anaang proverbs. JOSEH Vol 1. No 2. 62-77.

Finnegan, R. (1970). Oral literature in Africa. Oxford: Clarendon Press.

Finnegan, R. (2010). Studying the oral literatures of Africa in the 1960s and today', special issue, Journal des

africanistes $80,1 / 2$,

Finnegan, R. (2012). Oral literature in Africa, $\left(2^{\text {nd }}\right.$ ed.). Cambridge: Open Books Publishers.

Harding, L. (ed.), (1994). African Oral Traditions, special issue, Oral Tradition 9, 1,

Harding, F. (ed.), (2002). Performance Arts in Africa, London: Routledge,

Hymes, D. (1972). Models of the interaction of language and social life. In Gumperz J. and Hymes, D. (Eds.)

Directions in sociolinguistics: ethnography of communication, (pp35-71) New York: Holt, Rinehart \& Winston.

Hymes, D. (1974). Foundation of sociolinguistics: An ethnographic approach. Philadelphia: University of Pennsylvania Press.

Kabuta, N.S. (1998). Ideophones in Ciluba. Ghent: University Press.

Kunene, Daniel. P. (1978). The ideophone in Southern Sotho. Marburger studies Zur Africa-und Asienkunde. Serie A:

Africa Vol11. Berlin: Dietrich Reimer.

Lyons, J. (1977). Semantics. Vol. 2. Cambridge: CUP. 
Maduka, Omen N. (1988). "Size and shape ideophones in Nembe: A phonosemantic analysis.” Studies in African linguistics 19 (1): 93-113.

Makaryk, I. R. (Ed.) (2000). Encyclopedia of contemporary literary theory. Approaches, scholars, terms. Toronto: UP. Mensah, E. (2010). A morphosyntactic analysis of Efik proverbs. GLOSSA: Ambilingual Journal of Social Science and Humanities 5:250-81.

Messenger, J. C. (1959). The role of proverbs in the Nigerian judicial system. Southwestern Journal of Anthropology 15:63-73.

Messenger, J. C. (1960). 'Anang proverb-riddles', JAF 73, 15-35

Messenger, J.C. (1962). 'Anang art, drama and social control', Afr. studies bull 5, 2, 35-54

Michael, I. (2013). A socio-phonetic description of Anaang proverb-riddles. JLL4,2 77-89. http://dx.doi.org $10.7813 / \mathrm{j} 11.2013 / 4-2$

Noss, Phillip. A. (1975). The ideophone: A linguistic and literary device in Gbaya and Sango with reference to Sande. Khartoun: khartoun Press.

Noss, Phillip. A. 1985. The ideophones in Ggaya a Synta. In Dimendaal, J. (Ed.). Current approaches to African lyrics. Dordrecht: Foris Publications.

Noss, Phillip. A. (2001). The ideophones: a linguistic and literary device in Gbaya and Sango with reference to Sanda. Khartoum: Khartoum Press.

Oduaran, Akpovire, and Choja Oduaran. (2006). African proverbs as medium for fostering intergenerational relationships and communication in the Niger Delta, Nigeria African and Asian Studies 5 (2):215-29. Okpewho, I. (1992). African oral literature. Backgrounds, character, and continuity. Bloomington: Indiana University Press.

Salamone, F. (1976). The arrow and the bird: Proverbs in the solution of Hausa conjugal conflicts. Journal of Anthropological Research 32:358-71.

Schiffrin, D. (1994). Approaches to discourse. Oxford: Blackwell.

Searle, J. (1969). Speech acts : an essay in the philosophy of language. Cambridge: CUP.

Searle, J. (1979). Expression and meaning. Cambridge: CUP.

Sherzer, J. (1992). Ethnography of speaking. IEL 1:419-430

Simmons, Donald. C. (1955). 'Specimens of Efik folklore', Folklore 66. 2, 3-34

Stross, B. (1974). Speaking of speaking: Tenejapa Tzeltal metalinguistics. In Bauman, R. and Sherzer, J.

(Eds.)Explorations in the ethnography of speaking (Pp 213-239). Cambridge: CUP.

Udoh, I. I. (2003). Fortition and reduplication in Leggbo ideophones. Journal of African languages, Vol XXVIII, No $1.36-48$.

Ukut, S. (2010). A communicative analysis of Ibibio proverbs. USEM. JLLL V4.No2, 22-34

Yankah, K. (2012). Proverbs in the context of Akan rhetorics. New York: Diasporic African Press.

\section{Notes}

${ }^{1}$ Anaang belongs to a Lower Cross language group, of the Niger Congo family of African languages. The language is spoken in Akwa Ibom State of Southern Nigeria.

2. The translated version is also used by Finnegan (2012)

3. The data is presented in Anaang. A transliteration version of the data is added in bold form. This is followed by actual translation in italics. 